\title{
Contributions of Anterior Corneal and Ocular Residual Astigmatism to Autorefraction Astigmatism in a Myopic Adult Sample
}

This article was published in the following Dove Press journal: Clinical Ophthalmology

\author{
Amr A Gab-Alla (iD \\ Ophthalmology Department, Faculty of \\ Medicine, Suez Canal University, Ismailia, \\ Egypt
}

\begin{abstract}
Aim: To evaluate the contributions of anterior corneal and ocular residual astigmatism to autorefraction astigmatism in adult myopic and myopic astigmatic subjects and how these compensate each other.
\end{abstract}

Subjects and Methods: This retrospective study was completed in private eye centre, Ismailia, Egypt, between September 2017 and November 2019. The study included eyes with myopia ( 0.5 to $10.0 \mathrm{D})$ or myopic astigmatism ( 0 to $8.5 \mathrm{D})$. The refractive errors, including autorefraction astigmatism, were measured after using $1 \%$ cyclopentolate with autorefractometer (Topcon, Tokyo Optical Co., Ltd., Japan). Corneal topography (Sirius; CSO, Florence, Italy) was used to measure anterior corneal astigmatism. Ocular residual astigmatism was measured by vectorial subtraction of the anterior corneal astigmatism from autorefraction astigmatism determined to the corneal plane.

Results: This study included 1158 eyes (right 582 and left 576) with myopia or myopic astigmatism of 582 participants (206 males with 406 eyes and 376 females with 752 eyes). The mean \pm SD age of the total participants was $26 \pm 5.7$ years, range ( 21 to 50 years). The mean $\pm \mathrm{SD}$ of spherical error was $-3.2 \pm 1.9 \mathrm{D}$, range $(-0.5$ to $-10.0 \mathrm{D})$. The mean $\pm \mathrm{SD}$ of autorefraction astigmatism was $1.13 \pm 1.1 \mathrm{D}$; range $(0.5$ to $8.5 \mathrm{D})$. The mean $\pm \mathrm{SD}$ of anterior corneal astigmatism was $1.22 \pm 0.8 \mathrm{D}$; range (0.03 to $5.6 \mathrm{D})$. The mean $\pm \mathrm{SD}$ of ocular residual astigmatism was $0.6 \pm 0.5 \mathrm{D}$; range ( 0 to $4.8 \mathrm{D}$ ). Of the total eyes, $75.4 \%$ had significant autorefraction astigmatism, $82.5 \%$ had significant anterior corneal astigmatism, and $16.8 \%$ had significant ocular residual astigmatism.

Conclusion: The percentage of the significant autorefraction astigmatism $(>0.5 \mathrm{D})$ was $75.4 \%$ which is mainly anterior corneal. In $26.8 \%$ of participants, anterior corneal astigmatism is compensated by ocular residual astigmatism.

Keywords: astigmatism, anterior corneal astigmatism, ocular residual astigmatism, refractive surgeries

\section{Introduction}

Ocular astigmatism is a significant refractive condition as it is a common and correctable cause of visual deterioration, whether or not this exists with other spherical refractive errors. ${ }^{1}$ The prevalence of astigmatism $(>1.00 \mathrm{D})$ varies over a wide range through the different studies, from $17 \%$ to $63 \% .^{2-7}$

The origin of ocular astigmatism is not always purely corneal. ${ }^{8}$ Two components of astigmatism can be individually measured: autorefraction astigmatism (ARA) and anterior corneal astigmatism (ACA), which arises from the anterior corneal surface.
Correspondence: Amr A Gab-Alla Ophthalmology Department, Faculty of Medicine, Suez Canal University, Ring

Road, Ismailia, Egypt

Tel +20 I22283626I

Email amrophth@hotmail.com 
Ocular residual astigmatism (ORA) is herein defined as the vectorial difference between anterior corneal astigmatism and autorefraction astigmatism determined to the corneal plane..$^{9-12}$ It is known to be attributed to several factors, including posterior corneal astigmatism (PCA), anterior and posterior lenticular astigmatism, decentration of the crystalline lens, the variability of the refractive index, as well as from retinal tilt, high order aberrations (HOAs), and potentially cortical perception. ${ }^{13-17}$

Many reasons may confine the predictability of refractive correction carried out with different refractive surgeries. One of these reasons is the difference between autorefraction astigmatism and corneal astigmatism. ${ }^{18}$

The ORA parameter has been appeared to relate with the degree of residual astigmatism after kerato-refractive procedures for correction of refractive errors. ${ }^{18,19}$ Understanding of the distribution, the relationship between the different components of astigmatism and the compensation between anterior corneal and ORA is necessary for the outcome of refractive, and cataract surgeries. ${ }^{20}$

Therefore, this study aims to evaluate the contributions of anterior corneal astigmatism and ocular residual astigmatism to autorefraction astigmatism in adult myopic and myopic astigmatic subjects and how these compensate each other.

\section{Subjects and Methods}

This retrospective study was completed in private eye centre, Ismailia, Egypt, between September 2017 and November 2019. The study included eyes with myopia ( 0.5 to $10.0 \mathrm{D})$ or myopic astigmatism ( 0 to $8.5 \mathrm{D})$. The refractive errors, including autorefraction astigmatism, were measured after using $1 \%$ cyclopentolate with autorefractometer (Topcon, Tokyo Optical Co., Ltd., Japan). Corneal topography (Sirius; CSO, Florence, Italy) was used to measure anterior corneal astigmatism. Ocular residual astigmatism was measured by vectorial subtraction of the anterior corneal astigmatism from autorefraction astigmatism determined to the corneal plane. 9,10

The eligibility criteria included spherical myopia, myopic astigmatism, and a minimum age of 21 years with a regular corneal topography pattern. Patients with keratoconus, previous corneal or cataract surgeries were excluded from the study. Astigmatism and the astigmatic difference $(>0.5 \mathrm{D})$ will be considered being clinically significant in this study.

The study was reviewed and approved (approval No. 4197) by the research ethics committee of the Faculty of Medicine, Suez Canal University, in agreement with the
Declaration of Helsinki. No informed consent was required to review the medical records of the participants due to the retrospective nature of the study and the large number of them. The confidentiality of the participants' data was ensured, no further data will be shared.

\section{Statistical Analysis}

Data manipulation and analysis were performed by Statistical Package for the Social Sciences (SPSS version 25.0; IBM Corporation, Armonk, NY, USA). Baseline characteristics of the study population were presented as frequencies and percentages (\%) or mean values and standard deviations (SDs). Differences between means in the groups were compared by Student's $t$-test. Differences between frequencies in the groups were compared by the Chi-square test or Fisher's exact test (if $>20 \%$ of expected values were less than 5). Shapiro-Wilk's test was used to test for data normality. A $p$-value $<0.05$ was considered statistically significant. All graphs were performed with Graph Pad Prism (version 5.00 for Windows, Graph Pad Software, La Jolla California USA).

\section{Results}

This study included 1158 eyes (right 582 and left 576) with myopia or myopic astigmatism of 582 participants (206 males with 406 eyes and 376 females with 752 eyes). The mean \pm SD age of the total participants was 26 \pm 5 .7years, range ( 21 to 55 years). The mean \pm SD of spherical error was $-3.2 \pm 1.9 \mathrm{D}$, range $(-0.5$ to $-10.0 \mathrm{D})$. The mean $\pm \mathrm{SD}$ of the autorefraction astigmatism was 1.13 $\pm 1.1 \mathrm{D}$; range ( 0 to $8.5 \mathrm{D}$ ). The mean $\pm \mathrm{SD}$ of the anterior corneal astigmatism was $1.22 \pm 0.8 \mathrm{D}$; range (0.03 to $5.6 \mathrm{D})$. The mean $\pm \mathrm{SD}$ of the ocular residual astigmatism was 0.6 $\pm 0.5 \mathrm{D}$; range (0 to $4.8 \mathrm{D})$. Of the total eyes, $75.4 \%$ had significant autorefraction refractive astigmatism, $82.5 \%$ had significant anterior corneal astigmatism, and 16.8\%

Table I Mean and Percentage of the Autorefraction, Anterior Corneal, and Ocular Residual Astigmatism

\begin{tabular}{|c|c|c|c|c|}
\hline \multirow[t]{2}{*}{$\begin{array}{l}\text { Components of } \\
\text { Astigmatism }\end{array}$} & \multicolumn{2}{|c|}{$\begin{array}{l}\text { Descriptive Statistics } \\
n=1 / 58 \text { Eyes }\end{array}$} & \multicolumn{2}{|c|}{ Astigmatism n (Row \%) } \\
\hline & Mean \pm SD & Range & $<0.5 \mathrm{D}$ & $>0.5 \mathrm{D}$ \\
\hline Autorefraction & $1.13 \pm 1.1$ & 0 to 8.5 & 285 (24.6\%) & $873(75.4 \%)$ \\
\hline Anterior corneal & $1.22 \pm 0.8$ & 0.03 to 5.6 & 203 (17.5\%) & 955 (82.5\%) \\
\hline $\begin{array}{l}\text { Ocular residual } \\
\text { astigmatism. }\end{array}$ & $0.6 \pm 0.5$ & 0 to 4.8 & 964 (83.2\%) & $194(16.8 \%)$ \\
\hline
\end{tabular}




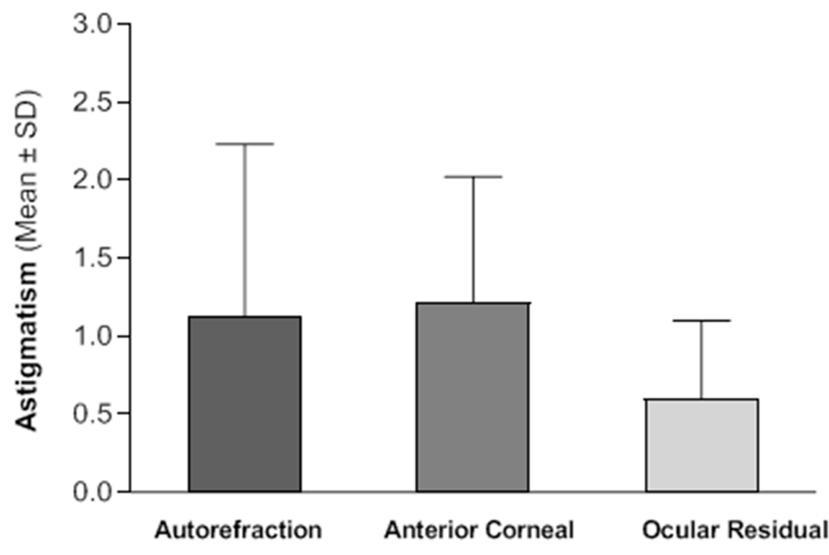

Figure I Mean of autorefraction, anterior corneal, and ocular residual astigmatism.

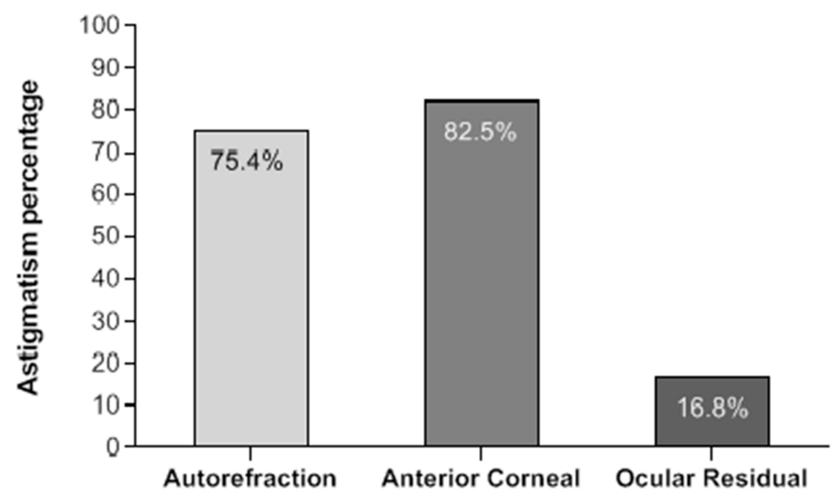

Figure 2 Percentage of significant autorefraction, anterior corneal, and ocular residual astigmatism $(>0.5 \mathrm{D})$.

had significant ocular residual astigmatism, Table 1 and Figures 1 and 2 .

The mean $\pm \mathrm{SD}$ age of the participants with significant autorefraction astigmatism was 28.0 \pm 7 .1years compared to $25.2 \pm 5.5$ years of the participants with insignificant autorefraction astigmatism $(P<0.001)$. The mean \pm SD spherical refractive error was $-3.5 \pm 2.5 \mathrm{D}$ of the participants with significant autorefraction astigmatism compared to $-3.4 \pm 2.0 \mathrm{D}$ of the participants with insignificant autorefraction astigmatism $(P=0.230)$. The mean \pm SD $\mathrm{K}$ min of the participants with significant autorefraction astigmatism was $43.3 \pm 1.6 \mathrm{D}$ compared to $43.6 \pm 1.3 \mathrm{D}$ of the participants with insignificant autorefraction astigmatism $(P=0.147)$. The mean $\pm \mathrm{SD} \mathrm{K}$ max was 44.8 $\pm 1.7 \mathrm{D}$ of the participants with significant autorefraction astigmatism compared to $44.2 \pm 1.4 \mathrm{D}$ of the participants with insignificant autorefraction astigmatism $(P<0.001)$. Autorefraction astigmatism was prevalent in females than males $(P=0.033)$, Table 2 .
Table 2 The Characteristics of Autorefraction Astigmatism

\begin{tabular}{|c|c|c|c|}
\hline \multirow[t]{2}{*}{ Characters } & \multicolumn{2}{|c|}{$\begin{array}{l}\text { Autorefraction Astigmatism } n=\mid \text { I } 58 \\
\text { Eyes } n \text { (Column \%) }\end{array}$} & \multirow[t]{2}{*}{$P$-value } \\
\hline & $\begin{array}{l}\text { Insignificant } \\
<0.5 D \\
n=285(24.6 \%)\end{array}$ & $\begin{array}{l}\text { Significant } \\
>0.5 D \\
n=873(75.4 \%)\end{array}$ & \\
\hline $\begin{array}{l}\text { Age (yrs): } \\
\quad \text { Mean } \pm S D \\
\text { Range }\end{array}$ & $\begin{array}{l}25.2 \pm 5.5 \\
(21 \text { to } 55)\end{array}$ & $\begin{array}{l}28.0 \pm 7.1 \\
\text { (21 to } 55)\end{array}$ & $<0.001 *$ \\
\hline $\begin{array}{l}\text { Sex: } \mathrm{n},(\%) \\
\quad \text { Male } \\
\text { Female }\end{array}$ & $\begin{array}{l}85(29.8 \%) \\
200(70.2 \%)\end{array}$ & $\begin{array}{l}321(36.8 \%) \\
552(63.2 \%)\end{array}$ & $0.033^{*}$ \\
\hline $\begin{array}{l}\text { Sphere (D): } \\
\text { Mean } \pm S D \\
\text { Range }\end{array}$ & $\begin{array}{l}-3.4 \pm 2.0 \\
(-1.0 \text { to }-10.0)\end{array}$ & $\begin{array}{l}-3.5 \pm 2.5 \\
(-0.5 \text { to }-10.0)\end{array}$ & 0.230 \\
\hline $\begin{array}{l}\text { K Min (D): } \\
\quad \text { Mean } \pm S D \\
\text { Range }\end{array}$ & $\begin{array}{l}43.6 \pm 1.3 \\
(39 \text { to } 47.5)\end{array}$ & $\begin{array}{l}43.3 \pm 1.6 \\
(39 \text { to } 49.5)\end{array}$ & 0.147 \\
\hline $\begin{array}{l}\text { K Max (D): } \\
\quad \text { Mean } \pm S D \\
\text { Range }\end{array}$ & $\begin{array}{l}44.2 \pm 1.4 \\
(39.5 \text { to } 48.2)\end{array}$ & $\begin{array}{l}44.8 \pm 1.7 \\
(39.9 \text { to } 51.4)\end{array}$ & $<0.00 I^{*}$ \\
\hline
\end{tabular}

Note: *Statistically significant.

Abbreviations: $\mathrm{n}$, number; yrs, years; SD, standard deviation; D, diopter; $\mathrm{K}$ min, minimum keratometric power; $\mathrm{K}$ max, maximum keratometric power.

The mean $\pm \mathrm{SD}$ age of the participants with significant anterior corneal astigmatism was 27.29 \pm 6.95 years compared to $27.19 \pm 6.23$ years of the participants with insignificant anterior corneal astigmatism $(P=0.858)$. The mean \pm SD spherical error was $-3.54 \pm 2.48 \mathrm{D}$ of the participants with significant anterior corneal astigmatism compared to$3.23 \pm 1.93 \mathrm{D}$ of the participants with insignificant anterior corneal astigmatism $(P=0.046)$. The mean \pm SD K min of the participants with significant anterior corneal astigmatism was $43.44 \pm 1.53 \mathrm{D}$ compared to $43.61 \pm 1.66 \mathrm{D}$ of the participants with insignificant anterior corneal astigmatism $(P=0.157)$. The mean \pm SD $\mathrm{K}$ max was $44.85 \pm 1.56 \mathrm{D}$ of the participants with significant anterior corneal astigmatism compared to $43.92 \pm 1.63 \mathrm{D}$ of the participants with insignificant anterior corneal astigmatism $(P<0.001)$, Table 3 and Figure 3.

The mean $\pm \mathrm{SD}$ age of the participants with significant ocular residual astigmatism was 30.6 \pm 8.4 years compared to $28.1 \pm 7.2$ years of the participants with insignificant ocular residual astigmatism $(P=0.001)$. The mean \pm SD spherical error was $-4.2 \pm 3.1 \mathrm{D}$ of the participants with significant ocular residual astigmatism compared to -3.6 $\pm 2.5 \mathrm{D}$ of the participants with insignificant ocular 
Table 3 The Characteristics of Anterior Corneal Astigmatism

\begin{tabular}{|c|c|c|c|}
\hline \multirow[t]{2}{*}{ Characters } & \multicolumn{2}{|c|}{$\begin{array}{l}\text { Anterior Corneal Astigmatism } \\
n=\mid \text { I } 58 \text { Eyes n (Column \%) }\end{array}$} & \multirow[t]{2}{*}{$P$-value } \\
\hline & $\begin{array}{l}\text { Insignificant } \\
<0.5 D \\
n=203(17.5 \%)\end{array}$ & $\begin{array}{l}\text { Significant } \\
>0.5 D \\
n=955(82.5 \%)\end{array}$ & \\
\hline $\begin{array}{l}\text { Age }(y r s) \text { : } \\
\text { Mean }( \pm S D) \\
\text { Range }\end{array}$ & $\begin{array}{l}27.19 \pm 6.23 \\
(21 \text { to } 53)\end{array}$ & $\begin{array}{l}27.29 \pm 6.95 \\
(21 \text { to } 55)\end{array}$ & 0.858 \\
\hline $\begin{array}{l}\text { Sex: } \mathrm{n},(\%) \\
\quad \text { Male } \\
\text { Female }\end{array}$ & $\begin{array}{l}82(40.4 \%) \\
12 \mid(59.6 \%)\end{array}$ & $\begin{array}{l}324(33.9 \%) \\
631(69.8 \%)\end{array}$ & 0.080 \\
\hline $\begin{array}{l}\text { Sphere }(D) \text { : } \\
\text { Mean }( \pm S D) \\
\text { Range }\end{array}$ & $\begin{array}{l}-3.23 \pm 1.93 \\
(-0.5 \text { to }-10.0)\end{array}$ & $\begin{array}{l}-3.54 \pm 2.48 \\
(-0.5 \text { to }-10.0)\end{array}$ & $0.046^{*}$ \\
\hline $\begin{array}{l}\text { K Min (D): } \\
\quad \text { Mean } \pm S D \\
\text { Range }\end{array}$ & $\begin{array}{l}43.61 \pm 1.66 \\
(39.02-49.5)\end{array}$ & $\begin{array}{l}43.44 \pm 1.53 \\
(38.74 \text { to } 49.5)\end{array}$ & 0.157 \\
\hline $\begin{array}{l}\text { K Max (D): } \\
\text { Mean } \pm S D \\
\text { Range }\end{array}$ & $\begin{array}{l}43.92 \pm 1.63 \\
(39.5 \text { to } 49.8)\end{array}$ & $\begin{array}{l}44.85 \pm 1.56 \\
(39.48 \text { to } 51.4)\end{array}$ & $<0.001 *$ \\
\hline
\end{tabular}

Note: *Statistically significant.

Abbreviations: $n$, number; yrs, years; SD, standard deviation; $D$, diopter; $K$ min, minimum keratometric power; $\mathrm{K}$ max, maximum keratometric power.
Table 4 The Characteristics of Ocular Residual Astigmatism

\begin{tabular}{|c|c|c|c|}
\hline \multirow[t]{2}{*}{ Characters } & \multicolumn{2}{|c|}{$\begin{array}{l}\text { Ocular Residual Astigmatism } \\
\text { n= I I58 Eyes } \\
\text { n (Column \%) }\end{array}$} & \multirow[t]{2}{*}{$p$-value } \\
\hline & $\begin{array}{l}\text { Insignificant }<0.5 D \\
n=964(83.2 \%)\end{array}$ & $\begin{array}{l}\text { Significant }>0.5 D \\
n=194(16.8 \%)\end{array}$ & \\
\hline $\begin{array}{l}\text { Age (yrs): } \\
\quad \text { Mean } \pm \text { SD } \\
\text { Range }\end{array}$ & $\begin{array}{l}28.1 \pm 7.2 \\
(21 \text { to } 53)\end{array}$ & $\begin{array}{l}30.6 \pm 8.4 \\
(21 \text { to } 50)\end{array}$ & $0.001 *$ \\
\hline $\begin{array}{l}\text { Sex: } \mathrm{n},(\%) \\
\quad \text { Male } \\
\text { Female }\end{array}$ & $\begin{array}{l}320(33.2 \%) \\
644(66.8 \%)\end{array}$ & $\begin{array}{l}86(44.3 \%) \\
108(55.7 \%)\end{array}$ & $0.003^{*}$ \\
\hline $\begin{array}{l}\text { Sphere (D): } \\
\text { Mean } \pm \text { SD } \\
\text { Range }\end{array}$ & $\begin{array}{l}-3.6 \pm 2.5 \\
(-0.5 \text { to }-10.0)\end{array}$ & $\begin{array}{l}-4.2 \pm 3.1 \\
(-0.5 \text { to }-10.0)\end{array}$ & $0.029 *$ \\
\hline $\begin{array}{l}\text { K Min }(D): \\
\text { Mean } \pm S D \\
\text { Range }\end{array}$ & $\begin{array}{l}43.35 \pm 1.66 \\
(39.3 \text { to } 48.0)\end{array}$ & $\begin{array}{l}43.52 \pm 1.88 \\
(40.5 \text { to } 51.4)\end{array}$ & 0.338 \\
\hline $\begin{array}{l}\text { K Max (D): } \\
\text { Mean } \pm S D \\
\text { Range }\end{array}$ & $\begin{array}{l}44.55 \pm 1.74 \\
(39.9 \text { to } 49.5)\end{array}$ & $\begin{array}{l}44.88 \pm 1.81 \\
(40.5 \text { to } 51.4)\end{array}$ & 0.056 \\
\hline
\end{tabular}

Note: *Statistically significant.

Abbreviations: $n$, number; yrs, years; $S D$, standard deviation; $D$, diopter; $K$ min, minimum keratometric power; $\mathrm{K}$ max, maximum keratometric power. residual astigmatism $(P=0.029)$. The mean \pm SD $\mathrm{K}$ min of the participants with significant ocular residual astigmatism was $43.52 \pm 1.88 \mathrm{D}$ compared to $43.35 \pm 1.66 \mathrm{D}$ of the participants with insignificant ocular residual astigmatism $(P=0.338)$. The mean \pm SD K max was $44.88 \pm 1.81 \mathrm{D}$ of the participants with significant ocular residual astigmatism

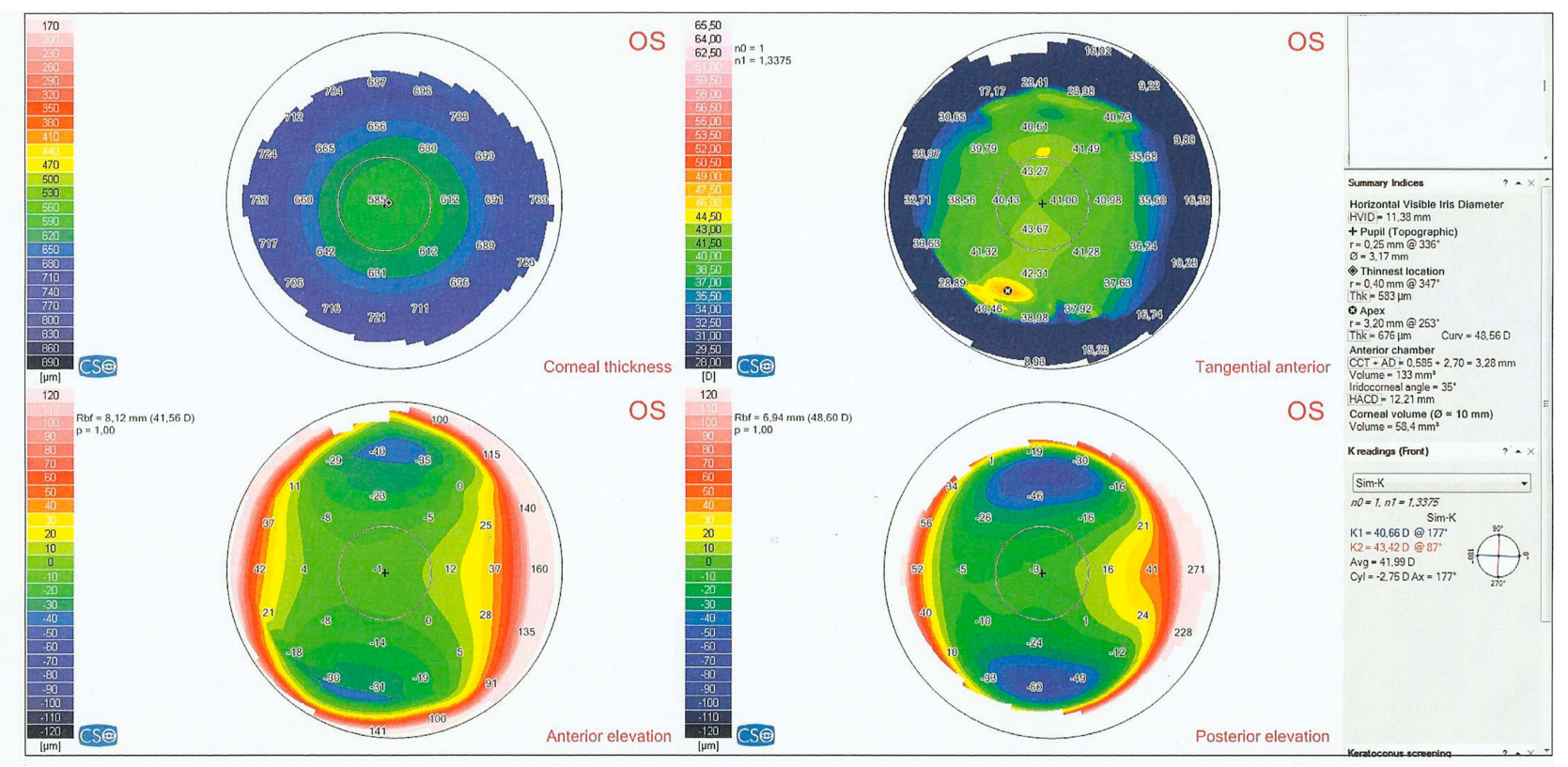

Figure 3 Corneal topography demonstrating anterior corneal astigmatism. 


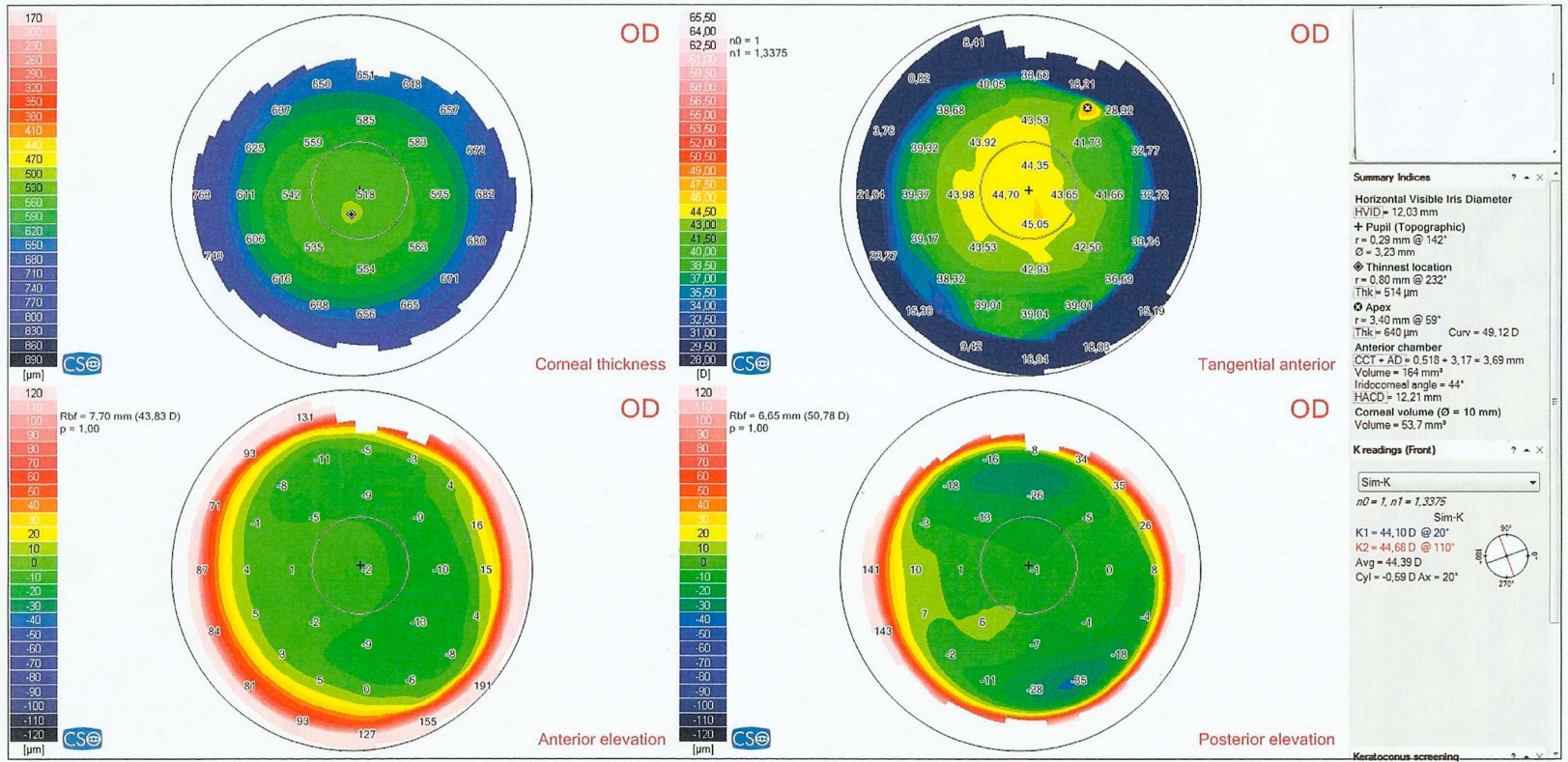

Figure 4 Corneal topography of ocular residual astigmatism.

compared to $44.55 \pm 1.74 \mathrm{D}$ of the participants with insignificant ocular residual astigmatism $(P=0.056)$, Table 4 and Figure 4.

Regarding the significant astigmatic difference (the difference in astigmatism $(>0.5 \mathrm{D})$ ), in $16.8 \%$ of the subjects, autorefraction astigmatism was more than anterior corneal astigmatism. In $26.8 \%$ of the subjects, anterior corneal astigmatism was more than autorefraction astigmatism. In $1.3 \%$ of the subjects, autorefraction and anterior corneal astigmatism were equal. In $0.3 \%$ of the subjects, anterior corneal and ocular residual astigmatism were equal. In $2.5 \%$ of the subjects, ocular residual astigmatism was more than anterior corneal astigmatism, Table 5 and Figure 5.
Regarding the significant astigmatic differences between autorefraction, anterior corneal, and ocular residual astigmatism according to the sex of the subjects: Autorefraction astigmatism exceeded anterior corneal astigmatism in $21.2 \%$ of males' eyes compared to $14.4 \%$ of females' eyes $\left(P=0.003^{*}\right)$. Anterior corneal astigmatism exceeded autorefraction astigmatism in $32.7 \%$ of females' eyes compared to $15.8 \%$ of males' eyes $(P=<0.001 *)$. Anterior corneal astigmatism exceeded ocular residual astigmatism in $19.5 \%$ of males' eyes compared to $17.8 \%$ of females' eyes $(P=0.492)$. Autorefraction astigmatism exceeded ocular residual astigmatism in $30.3 \%$ of males' eyes compared to $25.9 \%$ of females' eyes $(P=0.113)$, Table 6 and Figure 6.

Table 5 Percentage of the Significant Astigmatic Differences (>0.5D) Between Autorefraction, Anterior Corneal, and Ocular Residual Astigmatism $(\mathrm{n}=1158)$

\begin{tabular}{|c|c|c|c|c|c|}
\hline \multirow[t]{2}{*}{ Components of Astigmatism } & \multicolumn{2}{|c|}{ Astigmatic Difference } & \multicolumn{3}{|c|}{ Significant Astigmatic Difference $>0.5 \mathrm{D}$} \\
\hline & $\mathbf{n}$ & Mean $\pm S D$ Range & $\mathbf{n}$ & $\%$ of Astigmatic Difference & $\%$ of Total Eyes $=1158$ \\
\hline Autorefraction $>$ Anterior corneal & 420 & $0.59 \pm 0.52(0.1$ to 4.79$)$ & 194 & $46.2 \%$ & $16.8 \%$ \\
\hline Anterior corneal $>$ Autorefraction & 723 & $0.49 \pm 0.32(0.1$ to 2.1$)$ & 310 & $42.9 \%$ & $26.8 \%$ \\
\hline Autorefraction $=$ Anterior corneal & 15 & $1.02 \pm 0.78(0.5$ to 3.5$)$ & 15 & $100.0 \%$ & $1.3 \%$ \\
\hline Anterior corneal $=$ Ocular residual & 4 & $0.50 \pm 0.20(0.25$ to 0.75$)$ & 4 & $100.0 \%$ & $0.3 \%$ \\
\hline Anterior corneal $>$ Ocular residual & 313 & $1.08 \pm 0.8 \mathrm{I}(0.1$ to 4.7$)$ & 213 & $68.1 \%$ & $18.4 \%$ \\
\hline Ocular residual > Anterior corneal & 103 & $0.43 \pm 0.37(0.1$ to 2.19$)$ & 29 & $28.2 \%$ & $2.5 \%$ \\
\hline Autorefraction > Ocular residual & 420 & $1.28 \pm 0.95(0.1$ to 5.35$)$ & 318 & $75.7 \%$ & $27.5 \%$ \\
\hline
\end{tabular}

Abbreviations: SD, standard deviation; $n$, number. 


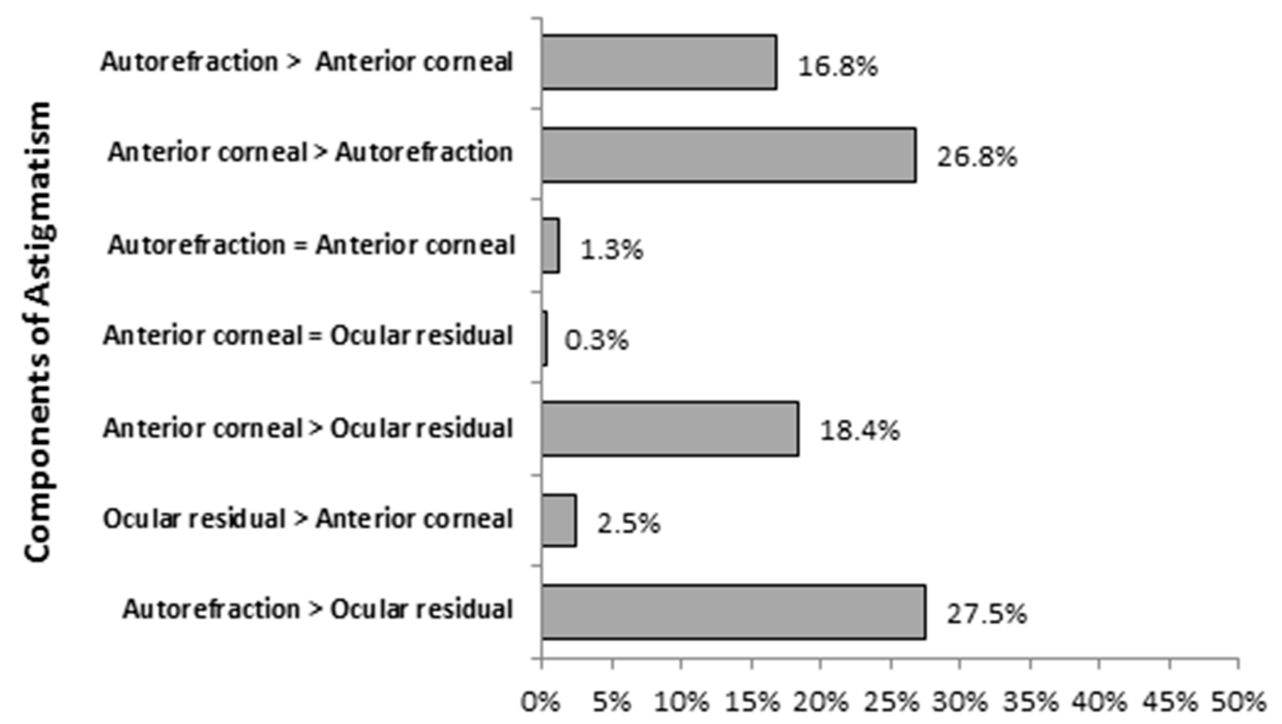

Figure 5 Percentage of the significant astigmatic differences (>0.5D) between autorefraction, anterior corneal, and ocular residual astigmatism ( $n=I$ I 58 ).

Regarding the significant astigmatic differences between autorefraction, anterior corneal, and ocular residual astigmatism according to the eye laterality of all participants: there were no statistically significant differences between them, Table 7 and Figure 7 .

\section{Discussion}

In the current study, anterior corneal and ocular residual astigmatism contributions to autorefraction astigmatism were evaluated by corneal topography, in adult, myopic participants have been examined. The prevalence rates of astigmatism between studies are difficult to compare due to the different definitions of astigmatism used in it, most studies used (0.5D) as an endpoint. This is usually considered being a clinically significant level of astigmatic error. ${ }^{21}$ Relevant to the present work, autorefraction astigmatism and ocular residual astigmatism $>0.50 \mathrm{D}$ were considered clinically significant. Accordingly, the prevalence of the significant astigmatisms of autorefraction, anterior corneal, and ocular residual astigmatism was $75.4 \%, 82.5 \%$, and $16.8 \%$, respectively. As regarding the significant astigmatic differences $(>0.50 \mathrm{D})$ between the autorefraction, anterior corneal, and ocular residual astigmatism, autorefraction astigmatism exceeded anterior corneal astigmatism only in $16.8 \%$ of the subjects; this means the autorefraction astigmatism was mainly driven by anterior corneal astigmatism. Anterior corneal astigmatism exceeded autorefraction astigmatism in $26.8 \%$ of the subjects which means that ocular residual astigmatism compensates anterior corneal astigmatism to minimize the magnitude of autorefraction astigmatism in this percentage of subjects which suggests the clinical importance of

Table 6 Percentage of the Significant Astigmatic Differences (>0.5D) Between Autorefraction, Anterior Corneal, and Ocular Residual Astigmatism According to the Sex of the Participants $(n=1158)$

\begin{tabular}{|l|l|l|l|l|}
\hline Components of Astigmatism & $\mathbf{n}$ & \multicolumn{2}{l|}{ Sex Total n=I I58 Eyes n (\%) } & P-value \\
\cline { 3 - 5 } & & Male n=406 Eyes & Female n=752 Eyes \\
\hline Autorefraction > Anterior corneal & 194 & $86(21.2 \%)$ & $108(14.4 \%)$ & $0.003 *$ \\
Anterior corneal > Autorefraction & 310 & $64(15.8 \%)$ & $246(32.7 \%)$ & $11(1.5 \%)$ \\
Autorefraction = Anterior corneal & 15 & $4(1.0 \%)$ & $2(0.3 \%)$ & $0.001 *$ \\
Anterior corneal = Ocular residual & 4 & $2(0.5 \%)$ & $134(17.8 \%)$ & 0.594 \\
Anterior Corneal > Ocular residual & 213 & $79(19.5 \%)$ & $15(2.0 \%)$ & $195(25.9 \%)$ \\
Ocular residual > Anterior corneal & 29 & $14(3.4 \%)$ & & 0.615 \\
Autorefraction > Ocular residual & 318 & $123(30.3 \%)$ & & 0.131 \\
\hline
\end{tabular}

Note: *Statistically significant $p$-value.

Abbreviation: $\mathrm{n}$, number. 


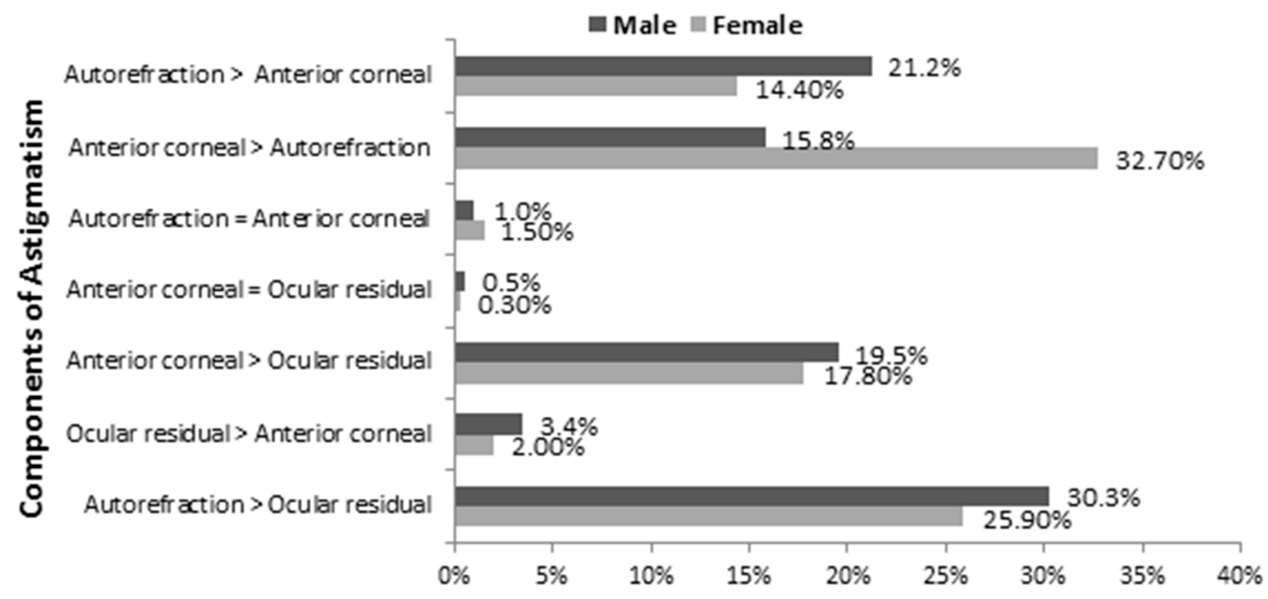

Figure 6 Percentage of the significant astigmatic differences ( $>0.5 \mathrm{D})$ between autorefraction, anterior corneal and ocular residual astigmatism according to the sex of the participants $(n=1158)$.

ocular residual astigmatism. Autorefraction astigmatism was equal to the anterior corneal astigmatism only in $1.3 \%$ of the subjects. The anterior corneal and ocular residual astigmatism were equal in only $0.3 \%$. In $18.4 \%$ of the subjects, anterior corneal astigmatism exceeded ocular residual astigmatism; ocular residual astigmatism exceeded anterior corneal astigmatism in $2.5 \%$. As regarding the significant astigmatic differences between autorefraction, anterior corneal and ocular residual astigmatism according to the sex of the participants and eye laterality was further analyzed. Autorefraction astigmatism was more common in males than females, while anterior corneal astigmatism was more common in both sexes. Also, there were no statistically significant differences between right and left eyes.
Even though the lenticular component might be an essential cause of refractive astigmatism in normal phakic subjects, in pseudophakic subjects, corneal astigmatism is thought of, the only significant factor. ${ }^{22}$ Understanding this fact is of benefit because the astigmatic error has a lot more noticeable impact on the possibility of spectacle use than overall error after routine cataract surgery. ${ }^{23}$ This data may be essential to correct astigmatism during cataract surgery, using corneal limbal relaxing incisions, toric ICL, and toric IOL implantation. Clinically observed discrepancies between corneal and refractive astigmatism are considered necessary when phacoemulsification is planned. The introduction of toric IOLs could have a possible role to counterbalance internal astigmatism, thus reducing total refractive astigmatic magnitude. ${ }^{23}$

Table 7 Percentage of the Significant Astigmatic Differences (>0.5D) Between Autorefraction, Anterior Corneal, and Ocular Residual Astigmatism According to the Eye Laterality of All Participants $(n=1$ I58)

\begin{tabular}{|c|c|c|c|c|}
\hline \multirow[t]{2}{*}{ Components of Astigmatism } & \multirow[t]{2}{*}{$\mathbf{n}$} & \multicolumn{2}{|c|}{$\begin{array}{l}\text { Eye Laterality } \\
\text { Total n= I I } 58 \\
\text { n (\%) }\end{array}$} & \multirow[t]{2}{*}{$P$-value } \\
\hline & & $\begin{array}{l}\text { Right } \\
n=582\end{array}$ & $\begin{array}{l}\text { Left } \\
n=576\end{array}$ & \\
\hline Autorefraction $>$ Anterior corneal & 194 & $95(16.3 \%)$ & 99 (I7.2\%) & 0.740 \\
\hline Anterior corneal > Autorefraction & 310 & $167(28.7 \%)$ & I 43 (24.8\%) & 0.350 \\
\hline Autorefraction $=$ Anterior corneal & 15 & $5(0.9 \%)$ & $10(1.7 \%)$ & 0.783 \\
\hline Anterior corneal $=$ Ocular residual & 4 & 0 & $4(0.7 \%)$ & 0.061 \\
\hline Anterior corneal > Ocular residual & 213 & $103(17.7 \%)$ & $110(19.1 \%)$ & 0.802 \\
\hline Ocular residual > Anterior corneal & 29 & $18(3.1 \%)$ & $11(1.9 \%)$ & 0.114 \\
\hline Autorefraction > Ocular residual & 318 & $152(26.1 \%)$ & 166 (28.8\%) & 0.928 \\
\hline
\end{tabular}




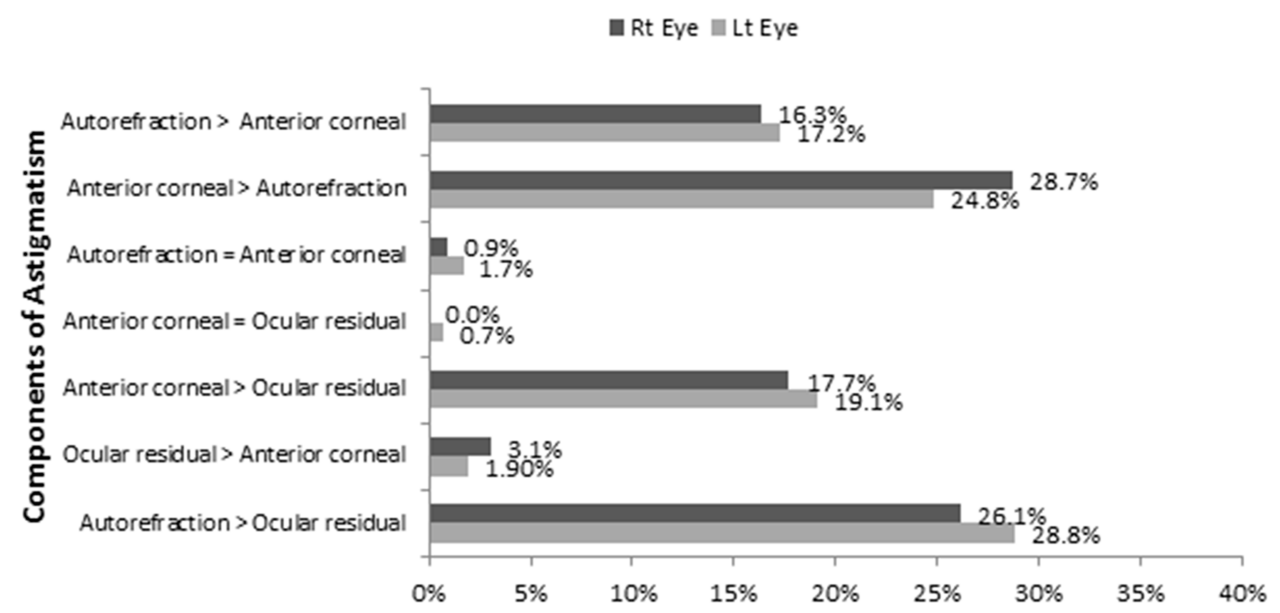

Figure 7 Percentage of the significant astigmatic differences ( $>0.5 \mathrm{D})$ between autorefraction, anterior corneal, and ocular residual astigmatism according to the eye laterality of all participants $(n=1158)$.

There are usually well-known drawbacks when selecting the proper treatment policy in corneal refractive surgery. One of those drawbacks is the treatment options that are based on topographic astigmatism only or manifest subjective astigmatism only to design the refractive treatment option. ${ }^{24,25}$ Previous studies ${ }^{18,26}$ recommend that LASIK treatment of astigmatism based on manifest subjective astigmatism results in a successful result only if the preoperative refractive astigmatism arises mainly from the anterior surface of the cornea.

Piñero et al. $^{27}$ reported that the magnitude of total refractive astigmatism did not appear to be a predictive factor for the efficacy of LASIK treatment of myopia or myopic astigmatism. The theoretical contribution of ocular residual astigmatism after LASIK to the total refractive astigmatism appears to be a critical factor for the occurrence of post-LASIK unexpected astigmatic residual refractive errors. They also concluded that attention should be taken with cases undergoing LASIK with relatively high ocular residual astigmatism because of its effect on the postoperative refractive cylinder and the predictability of refractive correction. This result still debated as many studies $^{28-30}$ analyzed the effect of ocular residual astigmatism on the effectiveness of LASIK for treating high myopic astigmatism. They reported no statistically significant differences in eyes with low or high ocular residual astigmatism on postoperative outcomes and concluded that in eyes with high myopic astigmatism undergoing LASIK, ocular residual astigmatism was not correlated with the residual postoperative cylinder.

The relative contribution of the optical aberrations of the cornea and the internal ocular optics mainly with the crystalline lens to overall aberrations in the human eye was investigated by Artal et al. ${ }^{31}$ They reported that the extent of aberration of both the cornea and the crystalline lens was more significant than for the total eye aberrations. This means that the cornea and the crystalline lens partially compensate for each other's aberrations and produce an improved retinal image and due to the fact the posterior cornea partially cancels the anterior corneal astigmatism. ${ }^{16}$ Park et al. ${ }^{32}$ calculated the ocular residual astigmatism (the difference between refractive and keratometric astigmatism) using corneal topography, and they found a significant compensation for corneal astigmatism by the ocular residual astigmatism. They also reported that the full compensation of corneal astigmatism by the ocular residual astigmatism was an uncommon finding, although under-compensation was the most common. On the other hand, Sayed ${ }^{33}$ concluded that ocular residual astigmatism compensation of corneal astigmatism was not supported in their study for astigmatism.

\section{Study Limitations}

The advantages and limitations of this study are worth to be mentioned. One of its advantages is the large sample size compared to other studies. Second, the study is in a uniform myopic population that would minimize the confounding effects due to variances in the refractions of the ocular components, and their interactions, which take place in different refractive groups due to the different geometric properties of these eyes. The third is the uniformity of the method of refraction, and the exclusion of ocular pathology. However, limitations of this study were the numbers of teenagers were underrepresented, also the 
unequal distribution of gender in the sample of the subjects. An additional disadvantage of this study is that the axial length of the eyes was not measured. This is because longer axial length specifies a larger eye, which might have different crystalline lens tilt and possibly foveal eccentricity compared to eyes with shorter axial length.

In conclusion, the percentage of the significant autorefraction astigmatism $(>0.5 \mathrm{D})$ is $75.4 \%$ which is mainly anterior corneal. In $26.8 \%$ of participants, anterior corneal astigmatism is compensated by ocular residual astigmatism. Preoperative evaluation of candidates for refractive surgeries should consider the relations between anterior corneal and ocular residual astigmatism as corneal refractive surgery is more effective in eyes with the astigmatic errors primarily originates from the cornea.

\section{Disclosure}

The author reports no funding and no conflicts of interest for this work.

\section{References}

1. Hwang HB, Kim HS, Kim MS, Kim EC. The effect of corneal higher-order aberrations on postoperative residual astigmatism after toric IOL implantation. Semin Ophthalmol. 2019;34(3):138-145. doi:10.1080/08820538.2019.1607399

2. Miller JM, Harvey EM, Schwiegerling J. Higher-order aberrations and best-corrected visual acuity in Native American children with a high prevalence of astigmatism. J AAPOS. 2015;19(4):352-357.e1. doi:10.1016/j.jaapos.2015.05.004

3. Hashemi H, Fotouhi A, Yekta A, Pakzad R, Ostadimoghaddam H, Khabazkhoob M. Global and regional estimates of prevalence of refractive errors: systematic review and meta-analysis. $J$ Curr Ophthalmol. 2017;30(1):3-22. doi:10.1016/j.joco.2017.08.009

4. Varma R, Torres M, McKean-Cowdin R, Rong F, Hsu C, Jiang X; Chinese American Eye Study Group. Prevalence and risk factors for refractive error in adult Chinese Americans: the Chinese American Eye Study. Am J Ophthalmol. 2017;175:201-212. doi:10.1016/j. ajo.2016.10.002

5. Galvis V, Tello A, Otero J, et al. Prevalence of refractive errors in Colombia: MIOPUR study. $\mathrm{Br} \quad J$ Ophthalmol. 2018;102 (10):1320-1323. doi:10.1136/bjophthalmol-2018-312149

6. Wang M, Cui J, Shan G, et al. Prevalence and risk factors of refractive error: a cross-sectional study in Han and Yi adults in Yunnan, China. BMC Ophthalmol. 2019;19(1):33. doi:10.1186/ s12886-019-1042-0

7. Theiss MB, Santhiago MR, Moraes HV Jr, Gomes BF. Prevalence of corneal astigmatism in cataract surgery candidates at a public hospital in Brazil. Arq Bras Oftalmol. 2019;82(5):377-380. doi:10.5935/ 0004-2749.20190071

8. Liu T, Thibos LN. Compensation of corneal oblique astigmatism by internal optics: a theoretical analysis. Ophthalmic Physiol Opt. 2017;37(3):305-316. doi:10.1111/opo.12364

9. Alpins NA, Goggin M. Practical astigmatism analysis for refractive outcomes in cataract and refractive surgery. Surv Ophthalmol. 2004;49:109-122. doi:10.1016/j.survophthal.2003.10.010

10. Alpins N. Practical Astigmatism Planning and Analysis. Thorofare, NJ, USA: SLACK Incorporated; 2017.
11. Frings A, Katz T, Steinberg J, Druchkiv V, Richard G, Linke S. Ocular residual astigmatism: effects of demographic and ocular parameters in myopic laser in situ keratomileusis. $J$ Cataract Refract Surg. 2014;40(2):232-238. doi:10.1016/j.jcrs.2013.11.015

12. Gauvin M, Wallerstein A. Astigmatic: an automatic tool for standard astigmatism vector analysis. BMC Ophthalmol. 2018;18(1):255. doi:10.1186/s12886-018-0920-1

13. Dubbelman M, Sicam VA, van der Heijde GL. The shape of the anterior and posterior surface of the aging human cornea. Vision Res. 2006;46(6-7):993-1001. doi:10.1016/j.visres.2005.09.021

14. Koch DD, Ali SF, Weikert MP, Shirayama M, Jenkins R, Wang L. Contribution of posterior corneal astigmatism to total corneal astigmatism. J Cataract Refract Surg. 2012;38(12):2080-2087. doi:10.1016/j.jcrs.2012.08.036

15. Reitblat O, Levy A, Kleinmann G, Abulafia A, Assia EI. Effect of posterior corneal astigmatism on power calculation and alignment of toric intraocular lenses: comparison of methodologies. J Cataract Refract Surg. 2016;42(2):217-225. doi:10.1016/j.jcrs.2015.11.036

16. Wallerstein A, Gauvin M, Cohen M. WaveLight ${ }^{\mathbb{B}}$ Contoura topography-guided planning: contribution of anterior corneal higher-order aberrations and posterior corneal astigmatism to manifest refractive astigmatism. Clin Ophthalmol. 2018;12:1423-1426. doi:10.2147/ OPTH.S169812

17. Wallerstein A, Gauvin M, McCammon K, Cohen M. Topographyguided excimer treatment planning: contribution of anterior corneal coma to residual ocular astigmatism. $J$ Cataract Refract Surg. 2019;45(6):878-880. doi:10.1016/j.jcrs.2019.02.041

18. Kugler L, Cohen I, Haddad W, Wang MX. Efficacy of laser in situ keratomileusis in correcting anterior and non-anterior corneal astigmatism: comparative study. J Cataract Refract Surg. 2010;36 (10):1745-1752. doi:10.1016/j.jcrs.2010.05.014

19. Qian YS, Huang J, Liu R, et al. Influence of internal optical astigmatism on the correction of myopic astigmatism by LASIK. $J$ Refract Surg. 2011;27(12):863-868. doi:10.3928/1081597X-20110629-01

20. Rozema JJ, Hershko S, Tassignon MJ. The components of adult astigmatism and their age-related changes. Ophthalmic Physiol Opt. 2019;39(3):183-193. doi:10.1111/opo.12616

21. Touzeau O, Gaujoux T, Bullet J, Allouch C, Borderie V, Laroche L. Relationships between refractive parameters: sphere, cylinder, and axis. J Fr Ophtalmol. 2012;35(8):587-598. doi:10.1016/j.jfo.20 11.12 .006

22. Hayashi K, Sato T, Yoshida M, Yoshimura K. Corneal shape changes of the total and posterior cornea after temporal versus nasal clear corneal incision cataract surgery. Br $J$ Ophthalmol. 2019;103 (2):181-185. doi:10.1136/bjophthalmol-2017-311710

23. Wilkins MR, Allan B, Rubin G; Moorfields IOL Study Group. Spectacle use after routine cataract surgery. $\mathrm{Br} J$ Ophthalmol. 2009;93(10):1307-1312. doi:10.1136/bjo.2008.151829

24. Alpins N, Stamatelatos G. Customized photoastigmatic refractive keratectomy using combined topographic and refractive data for myopia and astigmatism in eyes with forme fruste and mild keratoconus. J Cataract Refract Surg. 2007;33(4):591-602. doi:10.1016/j.jcrs.2006.12.014

25. Alpins N, Ong JK, Stamatelatos G. New method of quantifying corneal topographic astigmatism that corresponds with manifest refractive cylinder. $J$ Cataract Refract Surg. 2012;38 (11):1978-1988. doi:10.1016/j.jcrs.2012.07.026

26. Chan TCY, Wan KH, Kang DSY, Tso THK, Cheng GPM, Wang Y. Effect of corneal curvature on optical zone decentration and its impact on astigmatism and higher-order aberrations in SMILE and LASIK. Graefes Arch Clin Exp Ophthalmol. 2019;257(1):233-240. doi:10.1007/s00417-018-4165-8

27. Piñero DP, Ruiz-Fortes P, Pérez-Cambrodí RJ, Mateo V, Artola A. Ocular residual astigmatism and topographic disparity vector indexes in normal healthy eyes. Cont Lens Anterior Eye. 2014;37(1):49-54. doi:10.1016/j.clae.2013.07.006 
28. Labiris G, Gatzioufas Z, Giarmoukakis A, Sideroudi H, Kozobolis V. Evaluation of the efficacy of the Allegretto Wave and the Wavefront-optimized ablation profile in non-anterior astigmatisms. Acta Ophthalmol. 2012;90:e442-e446. doi:10.1111/j.1755-3768.2012.02463.x

29. Teus MA, Arruabarrena C, Hernandez-Verdejo JL, Canones R, Mikropoulos DG. Ocular residual astigmatism's effect on high myopic astigmatism LASIK surgery. Eye (Lond). 2014;28:1014-1019. doi:10.1038/eye.2014.133

30. Timothy J, Reinstein DZ, Pinero DP, Gobbe M, Carp GI. Comparison of the predictability of refractive cylinder correction by laser in situ keratomileusis in eyes with low or high ocular residual astigmatism. J Cataract Refract Surg. 2015;41:1383-1392. doi:10.1016/j.jcrs.2014.10.046
31. Artal P, Guirao A, Berrio E, Williams DR. Compensation of corneal aberrations by the internal optics in the human eye. J Vis. 2001;1 (1):1-8. doi:10.1167/1.1.1

32. Park CY, Oh JH, Chuck RS. Predicting ocular residual astigmatism using corneal and refractive parameters: a myopic eye study. Curr Eye Res. 2013;38(8):851-861. doi:10.3109/02713683.2013.790976

33. Sayed KM. Analysis of components of total astigmatism in infants and young children. Int Ophthalmol. 2017;37(1):125-129. doi:10.10 07/s10792-016-0244-1
Clinical Ophthalmology

\section{Publish your work in this journal}

Clinical Ophthalmology is an international, peer-reviewed journal covering all subspecialties within ophthalmology. Key topics include: Optometry; Visual science; Pharmacology and drug therapy in eye diseases; Basic Sciences; Primary and Secondary eye care; Patient Safety and Quality of Care Improvements. This journal is indexed on PubMed

Submit your manuscript here: https://www.dovepress.com/clinical-ophthalmology-journal

\section{Dovepress}

Central and CAS, and is the official journal of The Society of Clinical Ophthalmology (SCO). The manuscript management system is completely online and includes a very quick and fair peer-review system, which is all easy to use. Visit http://www.dovepress.com/ testimonials.php to read real quotes from published authors. 